\title{
Manajemen Komunikasi Partai Gerindra dalam Membangun Kepercayaan Publik di Kalangan Milenial
}

\author{
Samuella Natalia Emika, H.H. Daniel Tamburian \\ samuella.915160096@stu.untar.ac.id,_danielt@fikom.untar.ac.id
}

Fakultas Ilmu Komunikasi Universitas Tarumanagara

\begin{abstract}
Democratic politics is one of the systems used by the Indonesian state which Indonesia began to implement to independence in 1945. The Gerindra party was a party that was only formed in 2008 but was a party Gerindra still tried to compete with other parties by building trust in the community. In this study the authors use millennial topics. Of 225 million inhabitants in Indonesia, there are 81 million people aged 17-37 years referred to as millenials, this figure can be a direcion for political parties (Source: Suara.com). In this case, millenial trsut in the Gerindra party is needed. To build trust, management is needen in communication with millennials. This research uses decriptive qualitative approach with the case study method. The theoretical basis used in this research is communication management and building trust. In this process of finding this data using interview techniques and literature study. The informants chosen by the authors are three members of the DKI Jakarta DPRD part of the Gerindra Faction. The results of this study indicate that the Gerindra Party communication management utilizes party cadres, party wings and party loyalists. While in terms of building trust among the novice or millennial voters, the Gerindra Party provides evidence for five years leading the community, especially millennials and also with political regeneration, as well as carrying outprograms at the grassroots level.
\end{abstract}

Keywords: communication management, trust, millennial.

\begin{abstract}
Abstrak
Politik demokrasi merupakan salah satu sistem yang digunakan oleh negara Indonesia yang mulai diterapkan Indonesia pada kemerdakaan tahun 1945. Partai Gerindra terbilang partai yang baru dibentuk pada tahun 2008 namun partai Gerindra tetap berusaha menyaingi para partai-partai lain dengan membangun kepercayaan di masyarakat. Pada penelitian ini penulis menggunakan topik kalangan milenial. Dari 255 juta jiwa penduduk di Indonesia, ada sebanyak 81 juta jiwa berusia 17-37 tahun disebut sebagai kaum milenial, angka ini bisa menjadi penentu arah bagi partai politik. Dalam hal ini dibutuhkan kepercayaan dari kalangan milenial terhadap Partai Gerindra. Untuk membangun kepercayaan dibutuhkan suatu manajemen didalam komunikasi terhadap kaum milenial. Penelitian ini menggunakan pendekatan kualitatif deskriptif dengan metode studi kasus. Adapun landasan teori yang digunakan dalam penelitian ini adalah teori komunikasi, manajemen komunikasi serta membangun kepercayaan atau trust. Dalam proses pencarian data ini menggunakan teknik wawancara dan studi pustaka. Informan yang dipilih oleh penulis yaitu tiga anggota dari DPRD DKI Jakarta bagian Fraksi Gerindra. Hasil penelitian ini menunjukkan, manajemen komunikasi Partai Gerindra memanfaatkan kader partai, sayap partai dan loyalis partai. Sedangkan dalam hal membangun kepercayaan di kalangan milenial, Partai Gerindra memberikan bukti selama lima tahun ini memimpin kepada masyarkat terutama kaum milenial dan juga dengan regenerasi politik, serta menjalankan program-program pada masyarakat di tingkat bawah.
\end{abstract}


Kata Kunci: manajemen komunikasi, kepercayaan, milenial.

\section{Pendahuluan}

Politik demokrasi merupakan salah satu sistem yang digunakan oleh negara Indonesia yang mulai diterapkan Indonesia pada kemerdekaan tahun 1945. Dalam hal ini Indonesia dikatakan ada dalam tahap demokratisasi atau demokrasi yang kini tengah dibangun namun belum benar-benar berdiri dengan baik, hal ini bisa dilihat dari kurang adanya kesadaran politik di masyarakat untuk ikut ambil bagian dalam proses politik di Indonesia. Proses politik yang ada di Indonesia saat ini berada pada tingkat 'buruk'. Keterpurukan ini disebabkan oleh perpolitikan di Indonesia yang tidak sehat. Banyak sekali politisi yang terlibat kasus korupsi, karena mereka lebih mementingkan kepentingan pribadi dan akhirnya lupa akan tugasnya sebagai pejuang rakyat. (Sumber: Jurnal Sosial Politik Filsafat UGM). Dari keprihatinan inilah Fadli Zondan Hashim Djojohadikusumo melihat bahwa rakyat Indonesia hanya menjadi alat dan siapa saja yang tidak mempunyai kekuasaan ekonomi dan politik akan dengan sangat mudah menjadi korban. Mereka membicarakan politik terkini yang sangat jauh dari nilai demokrasi sesungguhnya.

Partai Gerindra di deklarasikan pada tanggal 6 Februari 2008, dengan menyuarakan visi, misi dan manifesto dari perjuangan partai Gerindra yakni agar terwujudnya masyarakat Indonesia yang merdeka, berdaulat, demokratis, bersatu, makmur dan adil serta beradab, berketuhanan serta berlandaskan pada Pancasila yang tercantum pada pembukaan Undang Undang Dasar tahun 1945. Partai Gerindra sudah dua kali mengikuti Pemilu yaitu tahun 2009 dan 2014, walau terbilang partai baru akan tetapi secara nasional mampu bersaing pada Pemilu 2009 dan 2014.

Kenaikkan posisi dalam pemilu ini tak luput juga dari dukungan masyarakat dan para pemilih pemula atau kaum milenial. Jumlah generasi milenial di Indonesia tergolong sangat besar. Jika merujuk pada data BPS, jumlah kaum milenial di Indonesia pada 2017, diperkirakan mencapai 85 juta jiwa. Jika dipersentasekan, angka tersebut mencapai 32,6 persen dari total populasi. Jumlah tersebut tergolong menarik dan menjanjikan apalagi bagi para politisi. Kaum milenial menjadi penentu bagi arah demokrasi Indonesia ke depan baik dalam pilkada maupun pemilu yang nantinya akan dilaksanakan.

Kenaikkan posisi dalam pemilu ini tak luput juga dari dukungan masyarakat dan para pemilih pemula atau kaum milenial. Dikutip dari laman berita Tirto.id tahun 2019, rata-rata jumlah kaum milenial sebanyak 23,77 persen dari banyaknya total populasi di Indonesia yang mencapai 268 juta jiwa. Artinya, hampir seperlima penduduk di Indonesia adalah kelompok milenial. Tergolong menarik dan menjanjikan apalagi bagi para politisi. Kaum milenial menjadi penentu arah demokrasi di Indonesia dalam pilkada dan pemilu yang dilaksanakan kedepan. Jumlah yang signifikan ini bisa memberikan kontribusi besar bagi bangsa ini. Terutama bagi kemenangan Calon Presiden dan Wakil Presiden pada pemilihan Presiden dan Wakil Presiden maupun pada pemilihan Anggota DPD, DPR dan DPRD atau Pemilu Legislatif.

Kondisi ini kerapkali tidak berlaku secara luas. Di Indonesia misalnya, apatisme terhadap politik tergolong masih cukup besar. Berdasarkan survei yang digelar CSIS pada periode 23-20 Agustus 2017, terlihat ketertarikan kaum milenial 
terhadap politik hanya 2,3 persen saja. Kondisi tersebut membuat politisi dan partai politik dituntut untuk bekerja ekstra untuk menarik perhatian kelompok pemilih besar tersebut.

Partai Gerindra dalam hal reposisi partai untuk beberapa tahun kedepan dituntut untuk memikirkan bagaiman acara untuk menggunakan bahasa, isu pemilih muda dan perempuan yang jumlahnya banyak di Indonesia. Pemilih pemula atau milenial masih banyak mengidap penyakit labilitas dan emosionalitas.

Peneliti terdahulu yang berjudul "Brand Activation, Strategi Komunikasi pada Lembaga Survei Politik Di Putaran Pertama Pilkada DKI Jakarta 2017" menyebutkan bahwa kepercayaan adalah yang utama, bagaimana cara menjaga independensi organisasi untuk tetap becitra positif di mata masyarakat atau publik.

Berdasarkan latar belakang yang telah diuraikan di atas, maka peneliti merumuskan bagaimana manajemen komunikasi Partai Gerindra dalam membangun kepercayaan public terutama bagi kaum milenial ? Tujuan penelitian ini adalah untuk mengetahui manajemen komunikasi dari Partai Gerindra. Untuk mengetahui cara Partai Gerindra dalam menaikkan suara pada kalangan kaum milenial dalam memilih Partai Gerindra. Untuk mengetahui cara Partai Gerindra dalam membangun kepercayaan publik.

\section{Metode Penelitian}

Penelitian ini menggunakan jenis penelitian kualitatif, menurut Sugiyono (2011), penelitian kualitatif merupakan metode penelitian yang berlandaskan filsafat post positivisme, peneliti sebagai instrumen kunci, pengambilan sampel data dengan purposive, snowball dan triangulasi, untuk hasil penelitian lebih menekankan makna dari pada generalisasi. Peneliti mengambil metode ini karena bertujuan mendapatkan hasil penelitian yang berupa kata, gambar namun bukan angka yang menunjukkan suatu kuantitas. Penlitian ini menggunakan metode studi kasus. Metode studi kasus ini diperlukan banyak informasi untuk mendapatkan bahan yang lebih luas, mendalam yang terdapat pada kasus dan permasalahan yang ada.

Penelitian ini menggunakan teknik pengumpulan data, seperti wawancara, studi kepustakaan, dan penelusuran data online. Subyek dalam penelitian ini yaitu anggota Partai Gerindra berdasarkan pada pilihan penelitian tentang aspek yang memfokuskan di penelitian ini. Peneliti mengambil tiga orang anggota DPRD DKI Jakarta dari Fraksi Gerindra. Adapun obyek penelitian ini yaitu manajemen komunikasi Partai Gerindra dalam membangun sebuah kepercayaan dengan publik atau masyarakat, khususnya di kalangan pemilih pemula atau milenial.

Teknik pengolahan dana analisis data yang peneliti gunakan yaitu kutipan Patton dalam Moleong, 2006: 280) analisis data merupakan proses mengatur urutan data, lalu mengorganisasikan ke dalam suatu kategori, pola, dan satuan uraian dasar. Proses pengolahaan data ini dimulai dengan mengelompokkan data yang terkumpul melalui wawancara daring atau online, lalu kajian pustaka dan penelusuran data online serta catatan yang dianggap menunjang dalam penelitian ini lalu diklasifikasikan dan dianalisa berdasarkan kepentingan pada penelitian.

Teknik keabsahan data yang digunakan penulis dengan menggunakan teknik pemeriksaan triangulasi dengan sumber, keabsahan data dan triangulasi dengan metode. Ahli Denzin (dalam Lexy J. Moleong, 2012:330) ia membedakan ada empat macam triangulasi sebagai teknik pemeriksaan yaitu memanfaatkan penggunaan sumber, penyidik, metode, serta teori. 


\section{Hasil Temuan dan Diskusi}

Hasil temuan dan diskusi, penulis bagi menjadi beberapa konsep-konsep pembahasan yaitu :

\section{Manajemen dalam Aktivitas Komunikasi}

Dalam menjalankan manajemen komunikasi, Partai Gerindra menggunakan sistem komunikasi dengan melemparnya ke kader atau masyarakat. Partai Gerindra membuka diri pada banyak pihak. Dengan menggunakan pendekatan yang humanis. Manajemen Komunikasi Partai Gerindra juga memanfaatkan media serta turun langsung ke masyarakat untuk mengenalkan partai Gerindra. Menurut Cutlip, Center, dan Broom's (2006), mendefinisikan suatu masalah adalah mencakup latar belakang masalah, melakukan penyelidikan dan memonitor opini, identifikasi pada kebutuhan publik, serta riset ilmiah berperan sangat penting dalam mendapatkan informasi untuk merumuskan strategis, tanpa adanya riset, maka tidak dapat memahami situasi dan memberikan solusi.

Dalam Partai Gerindra ada masalah yang secara jelas didefinisikan. Secara metode, proses riset ada dua, yaitu metode formal dan metode informal atau eksplorasi. Metode informal ini dilakukan dengan komunikasi personal, mewawancarai narasumber inti, survei, melalui telepon, mencari data melalui online, dan laporan lapangan metode formal. (Center dan Broom, 2009: 297306). Cara yang dilakukan Partai Gerindra cenderung ke metode informal. Ini ditunjukkan dengan cara Partai Gerindra yang berkomunikasi langsung dengan target komunikasi mereka.

Dalam perencanaan, terdapat dua mode. Menurut ahli Cutlip, Center, dan Broom (2009: 314), pertama planning mode lalu kedua evolutionary mode. Planning mode. adalah rencana yang sistematis dan panduan untuk mencapai tujuan organisasi sedangkan evolutionary mode merupakan strategi yang diterapkan selamanya serta mencirikan pola keputusan sehingga mampu menyesuaikan peluang atau ancaman organisasi. Maka Partai Gerindra memiliki menggunakan mode terencana (planning mode). Ini ditunjukkan dalam visi, misi, dan tujuan Partai Gerindra yang selalu menjadi landasan dalam mengkomunikasikan partai.

Adapun visi, misi dan tujuannya ditegaskan oleh salah satu narasumber yaitu selaras dengan visi dan misi Pak Prabowo dan Partai Gerindra. Satu membangun ekonomi yang kuta, berdaulat, adil dan makmur program aksi Partai Gerindra itu yang mereka tekankan ke masyarakat. Kemudian melaksanakan pemberdayaan ekonomi kerakyatan kemudian mengenai kedaulatan pangan dan energi serta pengamanan sumber daya air terus peningkatan kualitas pembangunan manusia (SDM) yaitu melalui pendidikan, kesehatan, dan sosial budaya terus juga infrastruktur, kelestarian pada alam. Kemudian juga membangun pemerintah yang didalamnya transparan, bebas dari korupsi, tegas, kuat dan efektif.

Menurut Cutlip, Center, dan Broom's (2006), komunikasi dan aksi adalah mengimplementasikan pada program tindakan dan komunikasi yang di desain mencapai suatu tujuan yang spesifik. Empat hal dalam aksi dan komunikasi adalah, tindakan nyata, komunikasi, dan identifikasi faktor (Cutlip, Center, \& Broom's, 2006). Partai Gerindra sangat berfokus pada tindakan nyata, khususnya dalam program-program dan organisasi masyarakat yang dibuat mereka. 
Gambar 1. Program Aksi Partai Gerindra

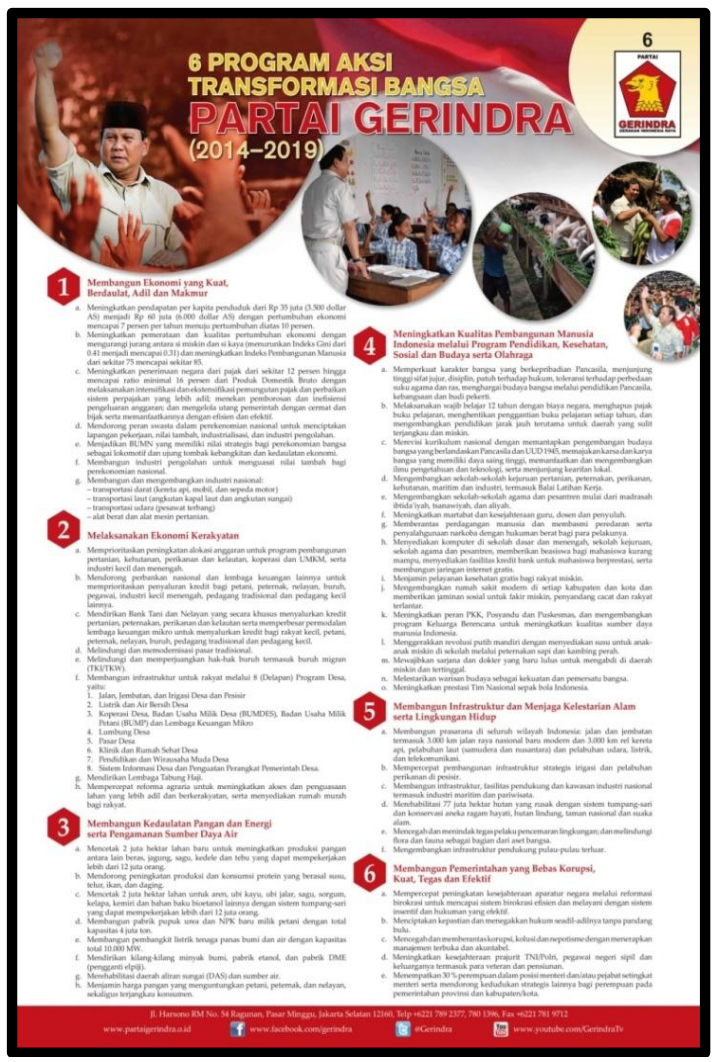

Sumber : Program Aksi Partai Gerindra

2. Kepercayaan (Trust)

Dalam membangun kepercayaan, khususnya pada kaum milenial, menurut salah satu narasumber menjelaskan bahwa Partai Gerindra memiliki perhatian khusus pada program tingkat bawah, yaitu dengan program Revolusi Putih, peduli terhadap gizi dan asupan susu pada anak-anak. Salah satu program yang telah dijalankan yaitu Program PMT-AS.

Gambar 2. Program Revolusi Putih di DKI Jakarta yaitu Program PMT-AS.

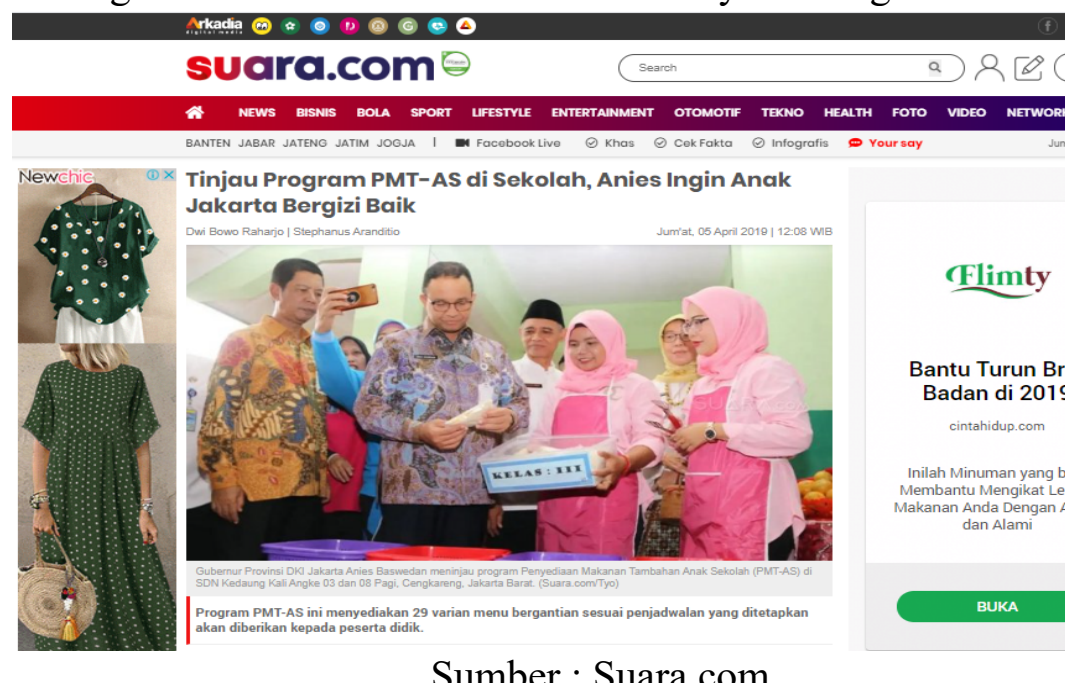

Sumber : Suara.com 
Program ini merupakan penerapan asupan tambahan untuk siswa. Mengacu pada aturan di Partai Gerindra berdasarkan program Revolusi Putih. Program ini diharapkan agar para penerus bangsa dari tingkat SD selama lima atau enam hari bersekolah mendapatkan asupan gizi terbaik yang disediakan oleh pemerintah.

Partai Gerindra dalam menaikkan suara pada pemilihan yang akan datang, harus membuktikan lima tahun kerja kita kedepan ini bisa memberikan efek yang besar dan maksimal kepada masyarakat. Partai Gerindra fokus pada program kerja dan mendengarkan suara dari milenial, dengan tidak mengubah pola komunikasi, tapi balik lagi kepada visi, misi dan tujuan dengan memberikan tanggung jawab kepada milenial untuk memilih.

Dalam membangun kepercayaan pada milenial juga dibutuhkan persiapan politik seperti yang dijelaskan oleh satu narasumber yaitu dalam mempersiapkan tongkat estafet pemimpin masa depan partai Gerindra berharap sepuluh duapuluh tahun kedepan itu jatuh kepada kaum milenial yang saat ini, apabila partai Gerindra mempersiapkan dari sekarang pemahaman politik yang baik, pemahaman ekonomi yang baik, serta sosial tentunya kaum milenial benar-benar siap menerima tongkat estafet ini.

Ada dua faktor yang mempengaruhi kepercayaan menurut ahli Job (2005) dan Putnam dalam Tranter dan Skrbis, 2009, yaitu faktor rasional dan relasional. Dalam kaitannya dengan milenial sebagai target, Partai Gerindra menggunakan dua isu tersebut dalam memperoleh kepercayaan dari milenial. Ini sejalan dengan penelitian sebelumnya oleh Dharma dan Fuady (2016), bahwa Partai Gerindra berfokus pada anak-anak muda dalam politik, khususnya sebagai regenerasi partai.

\section{Simpulan}

Berdasarkan hasil temuan serta analisis, maka peneliti mengambil beberapa kesimpulan sebagai berikut :

1. Manajemen dalam aktivitas komunikasi Partai Gerindra sudah diatur dan dirancang oleh ketua umum Gerindra Prabowo Subianto, dalam pelaksanaannya mengandalkan kader-kader dari Partai Gerindra.

2. Sasaran dari manajemen komunikasi partai Gerindra yaitu seluruh masyarakat di Indonesia dengan lebih condong kegolongan emak-emak dan kaum milenial.

3. Perencanaan program aksi partai Gerindra dengan memanfaatkan kader partai, sayap partai, dan loyalis partai.

4. Dalam membangun kepercayaan di kalangan milenial, Partai Gerindra menjalankan program di tingkat bawah, regenerasi politik, dan membuktikan kerja Partai Gerindra selama lima tahun kedepan.

5. Partai Gerindra fokus pada program kerja dan mendengarkan suara dari milenial, dengan tidak mengubah pola komunikasi, tapi balik lagi kepada visi, misi dan tujuan dengan memberikan tanggung jawab kepada milenial untuk memilih. 
Samuella Natalia Emika, H.H. Daniel Tamburian: Manajemen Komunikasi Partai Gerindra dalam Membangun Kepercayaan Publik di Kalangan Milenial

\section{Ucapan Terima Kasih}

Penulis mengucapkan terima kasih kepada ketiga informan yang telah bersedia memberikan informasi dan meluangkan waktu untuk Penulis selama proses skripsi ini. Penulis mengucapkan terima kasih kepada semua pihak dan Fakultas Ilmu Komunikasi Universitas Tarumanagara yang mendukung penulis selama penyusunan hingga skripsi ini selesai secara tepat waktu.

\section{Daftar Pustaka}

Candraningrum, Diah Ayu. (2017). Brand Activation, Strategi Komunikasi Pada Lembaga Survei Politik Di Putaran Pertama Pilkada DKI Jakarta 2017. Volume 1, Nomor 1.

Centre For Strategic and International Studies. (2017). Survei Nasional CSIS “Orientasi Sosial, Ekonomi dan Politik Generasi Milenial”. Juni 5, 2020.

https://www.csis.or.id/uploaded_file/event/ada_apa_dengan_milenial__pap aran_survei_nasional_csis_mengenai_orientasi_ekonomi_sosial_dan politik generasi milenial_indonesia notulen.pdf

Cutlip, Center \& Broom. (2006). Effective Public Relations (Edisi kesembilan) Jakarta: Kencana.

Cutlip, Scott. M., Center Allen H. \& Broom.Glen. M. (2009), Effective Public Relations, Ed. 9. Jakarta :Kencana.

Dharma, Yasser dan M. E Fuady. (2016). Strategi Komunikasi Politik Kader Muda Partai Gerindra. Prosiding Hubungan Masyarakat, 2 (1), 257-265. 2016. http://karyailmiah.unisba.ac.id/index.php/humas/article/viewFile/2991/pdf.

Garnesia, Irma. (2018, September 12). Sana-sini Ngaku Milenial, Bagaimana Peta Milenial Indonesia?. Juni 5, 2020. Tirto.id database.

https://tirto.id/sana-sini-ngaku-milenial-bagaimana-peta-milenial-indonesiacX5W

Kementrian Pemberdayaan Perempuan dan Perlindungan Anak. (2018). Statistik Gender Tematik : Profil Generasi Milenial Indonesia. Jakarta : BPS.

Moleong, Lexy. (2006). Metode Kualitatif. Bandung: PT. RemajaRosdaKarya.

Moleong, Lexy J. (2012). Metodologi Penelitian Kualitatif. Bandung : PT Remaja Rosdakarya.

Partai Gerindra. (n.d). 6 Program Aksi Partai Gerindra. Jun 04, 2020. http://partaigerindra.or.id/6-program-aksi-partai-gerindra.

Patton, yang dikutipolehLexy J. Moleong, 2010.

Raharjo, Dwi Bowo dan Stephanus Aranditio. (2019, April 05). Tinjau Program PMT- AS di Sekolah, Anies Ingin Anak Jakarta Begizi Baik. Juni 5, 2020. Suara.com. $\quad$ https://www.suara.com/news/2019/04/05/120850/tinjauprogram-pmt-as-di-sekolah-anies-ingin-anak-jakarta-bergizi-baik.

Rahardjo, SusilodanGudnanto. (2011). Pemahaman Individu Tekhnik Non Tes. Kudus: Nora Media Enterprise.

Sosial Politik Filsafat Fakultas Filsafat Universitas Gadjah Mada. 2017. Bagaimana Kondisi Sosial Politik di Indonesia ?. Juni 25, 2020. Terarsip di :

https://sosialpolitik.filsafat.ugm.ac.id/2017/08/21/bagaimana-kondisi-sosialpolitik-di-indonesia/).

Sugiyono. 2011. Metode Penelitian Kuantitatif, Kualitatif dan R\&D. Bandung: 
Vol. 4, No. 2, Oktober 2020, Hal 364 - 371

Afabeta.

Tranter, B \&Skrbis, Z. (2009). Trust and Confidence: A Study of Young Queenslanders. Australian Journal of Political Science, 659 - 678. 